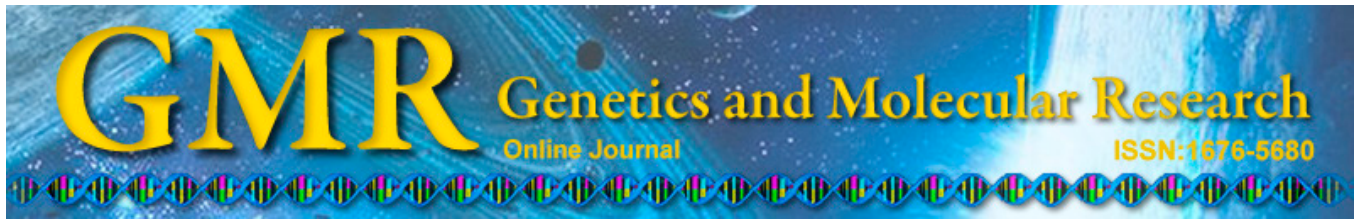

\title{
Vasoactive intestinal polypeptide suppresses proliferation of human cord blood-derived hematopoietic progenitor cells by increasing TNF- $\alpha$ and TGF- $\beta$ production in the liver
}

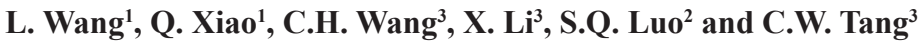 \\ ${ }^{1}$ Department of Hematology, \\ The First Affiliated Hospital of Chongqing Medical University, \\ Chongqing, China \\ ${ }^{2}$ Department of General Surgery, \\ The First Affiliated Hospital of Chongqing Medical University, \\ Chongqing, China \\ ${ }^{3}$ Division of Peptides Related with Human Diseases, \\ State Key Laboratory of Biotherapy of Human Diseases, \\ West China Hospital, Sichuan University, Chengdu, China
}

Corresponding author: S. Luo

E-mail: luoshiqiao@hotmail.com

Genet. Mol. Res. 13 (4): 9032-9043 (2014)

Received September 16, 2013

Accepted May 10, 2014

Published October 31, 2014

DOI http://dx.doi.org/10.4238/2014.October.31.18

\begin{abstract}
The physiology of hepatic hematopoiesis is largely unknown, although studies have indicated that vasoactive intestinal polypeptide (VIP) is involved in this disease. To validate this hypothesis, we assessed the effects of VIP on human cord blood CD34 $4^{+}$ cells. We also measured VIP levels and the capacity of vasoactive intestinal polypeptide receptor (VIPR) to bind to VIP in the rat liver during different developmental phases. VIP inhibited the proliferation of cord blood-derived CD34+ cells from concentrations of $10^{-7}-10^{-12}$ M. The highest suppression was achieved with $10^{-8} \mathrm{M}$ VIP at day 10 .
\end{abstract}


Intracellular levels of tumor necrosis factor (TNF)- $\alpha$ and transforming growth factor (TGF) $-\beta_{1}$ in CD34 ${ }^{+}$cells treated with VIP were increased by 50.70 and $43.46 \%$, respectively. Variations in VIP levels in the rat fetal liver generally increased rapidly with the stage of fetal development. In addition, the affinity of VIPR for VIP increased from relatively low levels in the rat fetal liver and peaked at birth, after which it gradually decreased. VIP had a suppressive effect on the proliferation of human cord blood-derived $\mathrm{CD} 34^{+}$cells, partially by increasing the production of TNF- $\alpha$ and TGF- $\beta$. Low VIP levels in the fetal liver and gradually increasing levels after birth may in part be responsible for suppressing hematopoietic stem cell and progenitor proliferation in the liver.

Key words: Cord blood cells; Fetal development; Hepatic hematopoiesis; Vasoactive intestinal polypeptide

\section{INTRODUCTION}

Vasoactive intestinal polypeptide (VIP), a 28-amino acid neuropeptide, is secreted from endocrine cells in the gastrointestinal tract and is delivered to the liver through the portal bloodstream. After being captured and internalized by hepatocytes, VIP is degraded by lysosomes (Misbin et al., 1982). VIP induces multiple biological effects, including immune system regulation, indicating its potential therapeutic use (Smalley et al., 2009). VIP has been shown to be involved in the regulation of organ development such as the lungs, brain, and intestines (Leister et al., 2005).

However, the physiological functions of VIP in the liver remain unclear. Hepatic hematopoiesis begins during the 6th week of gestation and continues for approximately the first 6 months of embryo development. Hepatic hematopoiesis is also controlled by the intrinsic microenvironment and humoral factors from the liver (Si-Tayeb et al., 2010), which is similar to hematopoiesis in the bone marrow after birth. Although a few genes have been identified as relevant to this process, including a number of transcription factors (Tober et al., 2008; Khurana et al., 2010) and some neurotransmitters (Turtzo et al., 2001; Sreepriya and Bali, 2006), the mechanisms regulating liver hematopoiesis remain unknown. We hypothesized that VIP plays an important role in regulating hepatic hematopoiesis during fetal life, based on findings that specific VIP receptors (VIPRs) are expressed in fetal liver cells before morphological and functional differentiation of these cells (Kim et al., 2011). The biological functions of VIP are mediated by 2 receptors [vasoactive intestinal peptide receptor type 1 (VPAC1R) and type 2 (VPAC2R)]. The VIP-VIPR dimer in the liver may be a humoral effector that regulates hematopoiesis in the fetal liver.

To elucidate the possible function of VIP on hepatic hematopoiesis, the present study examined the variation in expression of VIP in rat livers at different phases of development, and the effects of VIP on hematopoietic stem/progenitor cells derived from human cord blood in vitro. The study identified that VIPR-1 was expressed in both fetal liver and cord bloodderived $\mathrm{CD}_{3} 4^{+}$cells, suggesting that VIP plays an important role in fetal liver via binding with VIPR-1. Due to obvious ethical reasons, the experiments performed in rats could not be performed in human fetal livers. However, the rat fetal liver has proven to be a suitable model for hematopoiesis research, since they have the same function of hematopoiesis as human fetal livers (Fiegel et al., 2003; Sato et al., 2004; Schmelzer et al., 2008). 


\section{MATERIAL AND METHODS}

\section{Human umbilical cord blood samples}

Thirty human umbilical cord blood samples were obtained from the Second West China Hospital affiliated with the Sichuan University. Informed consent was obtained from all patients after gaining approval from the Clinical Committee of the hospital. Umbilical cord blood from normal delivery was collected in a sterile bag containing citrate-phosphate-dextrose.

\section{Animals}

Sprague-Dawley rats were provided by the Experimental Animal Center of Sichuan University. Rats were divided into 4 groups ( $N=6$ /group) representing 4 different phases of development: 14-day fetuses (fetuses), 1-day neonates (neonate), 6 weeks after birth (premature), and 4 months after birth (adult). Livers were removed directly from fetal or neonatal rats without anesthesia, or were removed from young and adult rats after anesthesia with methyl ether. Samples were rapidly frozen at $-80^{\circ} \mathrm{C}$ after removal from rats. All animal experiments were approved by the Experimental Animal Review Board of Sichuan University.

\section{Reagents}

VIP-28 was purchased from Saxon Biochemicals GmbH (Hanover, Germany). The BIAcore sensor chip CM-5 was obtained from BIAcore AB (Uppsala, Sweden). The [125I]-VIP radioimmuno kit was provided by Haikerui, Ltd. (Beijing, China). All reverse transcription (RT)-polymerase chain reaction (PCR) reagents were obtained from Fermentas (Hanover, Germany) or Invitrogen (Carlsbad, CA, USA). In this study, we also used the following reagents: rhSCF, rhFLT3-L, and IL-3 (PeproTech; Rocky Hill, NJ, USA), StemSpan serum-free medium and Methocult GF H4434 methylcellulose medium (StemCell Technologies; Vancouver, Canada), anti-CD34, anti-CD33, anti-CD38, anti-CD13, anti-CD14, anti-CD71, anti-CD41, anti-CD19, anti-CD4, and anti-CD8 antibodies (BD Biosciences; Franklin Lakes, NJ, USA).

\section{Preparation of $\mathrm{CD}^{+} 4^{+}$cells}

Cord blood was diluted by adding HANKS buffer, $\mathrm{pH}$ 7.4, and was then carefully added onto Ficoll-Hypaque $\left(1.077 \mathrm{~g} / \mathrm{cm}^{3}\right)$, followed by density gradient centrifugation at 2012 $g$ for $25 \mathrm{~min}$. Mononuclear cells (MNCs) were aspirated from the interface between the plasma and Ficoll and were washed 2 times in phosphate-buffered saline (PBS).

CD34 ${ }^{+}$cells were purified from cord blood MNCs by automated magnetic cell sorting for positive selection (Miltenyi Biotec; Bergisch Gladbach, Germany). MNCs were mixed with anti-CD34 $4^{+}$microbeads at $4^{\circ} \mathrm{C}$, and were passed through mini columns twice according to manufacturer instructions. The number of purified CD34+ cells was determined. Cell viability was determined by trypan blue staining. Cells were then incubated with PE-anti-CD34, and the purity of the enriched CD $34^{+}$cells was tested using flow cytometry.

\section{Colony forming unit (CFU) assay}

Automated magnetic cell sorting-enriched CD $34^{+}$cells $\left(0.25 \times 10^{5} / \mathrm{mL}\right)$ were cultured 
on 24-well plates in methylcellulose medium (Methocult GF H4434), containing 30\% fetal calf serum, $1 \%$ bovine serum albumin, $10^{-4} \mathrm{M}$ 2-mercaptoethanol, $2 \mathrm{mM}$ L-glutamine, $1 \%$ methylcellulose - Iscove's Modified Dulbecco's Medium, $50 \mathrm{ng} / \mathrm{mL}$ recombinant human Stem Cell Factor, $2 \mathrm{ng} / \mathrm{mL}$ recombinant human Interleukin-3, $10 \mathrm{ng} / \mathrm{mL}$ recombinant human Granulocyte-Macrophage Colony-Stimulating Factor, and $3 \mathrm{U} / \mathrm{mL}$ Erythropoietin, VIP concentrations in the medium varied from $10^{-12}-10^{-7} \mathrm{M}$. Cells were cultured at $37^{\circ} \mathrm{C}$ and $5 \% \mathrm{CO}_{2}$ in a humidified atmosphere. A single blinded observer counted colonies at days 7,10 , and 14 . The inhibition ratio of CFU (\%) was determined in 6 samples taken from each different development group and were counted in triplicate.

\section{Serum-free liquid culture}

$\mathrm{CD}^{+}{ }^{+}$cells were cultured on 24-well plates in Stemspan serum-free medium. The starting cell concentration was $1 \times 10^{4} / \mathrm{mL}$, with a VIP concentration of $10^{-8} \mathrm{M}$. Human growth factors used included $50 \mathrm{ng} / \mathrm{mL}$ stem cell factor (SCF), $50 \mathrm{ng} / \mathrm{mL}$ flt $3-\mathrm{L}, 50 \mathrm{ng} / \mathrm{mL}$ GM-CSF, $10 \mathrm{ng} / \mathrm{mL}$ IL-3, and $3 \mathrm{U} / \mathrm{mL}$ EPO. Cells were cultured at $37^{\circ} \mathrm{C}$ and $5 \% \mathrm{CO}_{2}$ in a humidified atmosphere and analyzed on days 7, 10, and 14 using 6 samples for each group in duplicate.

\section{Measurement of tumor necrosis factor (TNF)- $\alpha$ and transforming growth factor (TGF)- $\beta$ in human $\mathrm{CD34}^{+}$cells by enzyme-linked immunosorbent assay (ELISA)}

Cells were harvested from serum-free liquid culture with or without $10^{-8} \mathrm{M}$ VIP after 7 days of culture. Cells were subjected to repeated freezing and thawing. Cell-free extracts were collected after centrifugation at $1200 \mathrm{rpm}$ for $5 \mathrm{~min}$ and stored at $-70^{\circ} \mathrm{C}$. The supernatant was also collected and stored at $-70^{\circ} \mathrm{C}$. Before the assay, samples were thawed at room temperature and a human TNF- $\alpha /$ TGF- $\beta$ ELISA kit (DSL, Inc.; Webster, TX, USA) was used according to the manufacturer protocol. Optical density values were assessed at $450 \mathrm{~nm}$ using a spectrophotometer (M550; Bio-Rad; Hercules, CA, USA). Measurements were performed in triplicate for each sample. TNF- $\alpha$ and TGF- $\beta$ concentrations were determined from a standard curve established using standards of known concentrations.

\section{Measurement of VIP in liver tissue by radioimmunology assay}

\section{Preparation of tissue homogenate}

To prepare the tissue homogenate, $100 \mathrm{mg}$ rat liver samples were mixed with $0.5 \mathrm{~mL}$ $1 \mathrm{~N}$ acetic acid, homogenized using an ultrasound homogenizer (Sonics and Materials, Inc.; Newtown, CT, USA), and then neutralized with $0.5 \mathrm{~mL} 1 \mathrm{~N} \mathrm{NaOH}$. The entire process was carried out on ice. Samples were vortexed and centrifuged at $3000 \mathrm{rpm}$ for $30 \mathrm{~min}$ at $4^{\circ} \mathrm{C}$. The supernatant was removed and stored at $-80^{\circ} \mathrm{C}$.

\section{Radioimmunoassay}

Briefly, $0.3 \mathrm{~mL}$ tissue homogenate from each sample was added to $0.1 \mathrm{~mL}$ anti-VIP monoclonal antibody. The mixture was incubated for $48 \mathrm{~h}$ at $4^{\circ} \mathrm{C}$. Next, $100 \mu \mathrm{L}$ [ $\left.{ }^{125} \mathrm{I}\right]$-VIP was added, the mixture was incubated for $48 \mathrm{~h}$ at $4{ }^{\circ} \mathrm{C}$, and $0.6 \mathrm{~mL}$ precipitation solution was 
added. Samples were mixed and placed on ice for 20 min followed by centrifugation at 3000 $\mathrm{rpm}$ for $15 \mathrm{~min}$. The supernatant was discarded and the precipitate was assessed using a $\gamma$ counter. VIP concentration was determined using the $\gamma$ counter analysis software. All assays were performed in triplicate.

\section{Measurement of VIPR in liver tissue}

\section{Extraction of total protein}

Total protein was extracted from $100 \mathrm{mg}$ liver tissue, quantified, and stored at $-80^{\circ} \mathrm{C}$. Briefly, $100 \mathrm{mg}$ liver samples were homogenized in ice-cold PBS and centrifuged to pellet the hepatocytes. The cell pellet was resuspended in $1 \mathrm{~mL}$ total protein extracting buffer (50 $\mathrm{mM}$ Tris, $\mathrm{pH} 7.4,150 \mathrm{mM} \mathrm{NaCl}, 5 \mathrm{mM}$ ethylenediamine tetraacetic acid, 1\% Triton X-100) containing $20 \mu \mathrm{L}$ protease inhibitor, and $5 \mu \mathrm{L} / \mathrm{mL}$ phenylmethyl sulfonyl fluoride. The mixture was incubated on ice for $30 \mathrm{~min}$ followed by centrifugation at 12,000 rpm for $20 \mathrm{~min}$ at $4^{\circ} \mathrm{C}$. The supernatant containing proteins was transferred to a fresh tube, $10 \mu \mathrm{L}$ protein was sampled, and the concentration was determined on 96-well polystyrene plates (M550; BioRad). Bovine serum albumin was used as a standard (Sigma; St. Louis, MO, USA).

\section{VIPR analysis with a biomolecular interaction analysis system}

A biomolecular interaction analysis system (BIAcore X; Amersham Biosciences; Uppsala, Sweden) was used to measure the binding capacity between VIP and its receptors. Pure 28-amino acid VIP was immobilized onto BIAcore sensor chips CM-5 after activation using a 1:1 mixture of 1-ethyl-3-(3-dimethylaminopropyl) carbodiimide and $N$-hydroxysuccinimide, according to manufacturer instructions. The remaining active groups on the matrix were blocked with $1 \mathrm{M}$ ethanolamine- $\mathrm{HCl}$ at $\mathrm{pH}$ 8.5. Interaction studies were performed in running buffer [PBS containing $1 \%(\mathrm{v} / \mathrm{v})$ dimethyl sulfoxide and $0.05 \%(\mathrm{v} / \mathrm{v})$ Tween 20]. Protein samples were injected onto an immobilized VIP protein chip at a flow rate of $30 \mu \mathrm{L} / \mathrm{min}$. The raw data from individual binding experiments were measured using the BIAevaluation software (Amersham Biosciences). BIAcore sensor chips CM5 were used throughout all experiments, and all solutions were filtered ( $0.22 \mu \mathrm{m}$; Millipore; Billerica, MA, USA) and degassed before use. Baseline fluctuations were \pm 5 resonance units (RU). Data were normalized to RU/ $\mu \mathrm{g}$ protein. Specific binding $=$ total binding - nonspecific binding.

\section{RT-PCR for VIPR subtype}

Total RNA was isolated from 50-100 mg liver tissue and from cord blood-derived $\mathrm{CD}_{4}{ }^{+}$cells using TRIzol reagent according to manufacturer instructions. Next, $2 \mu \mathrm{g}$ total RNA was reverse-transcribed using $6 \mu \mathrm{g}$ random primers and $200 \mathrm{U}$ M-MLV RT in reaction buffer supplemented with $10 \mathrm{nM}$ dithiothreitol, $40 \mathrm{U}$ Rnasin, and $0.5 \mathrm{mM}$ deoxyribonucleotides. Next, $4 \mu \mathrm{L}$ RT reaction products were then PCR-amplified using specific primers. Primer sequences were: rat VIPR-1: sense 5'-CAG CCC GCA GCA CGA GT-3', antisense 5'-AGC AGC CAG AAG AAG TT-3'; rat VIPR-2: sense 5'-GCG AGA CTG AGG AAA TC-3', antisense 5'-GTC CCA GCA ACC TGT GTC TTC TA-3' (Usdin et al., 1994; Ohnami et al., 1999). The PCR protocol was denaturation at $94^{\circ} \mathrm{C}$ for $5 \mathrm{~min}$, followed by 35 cycles at $96^{\circ} \mathrm{C}$ 
for $1 \mathrm{~min}, 55^{\circ} \mathrm{C}$ for $1 \mathrm{~min}, 72^{\circ} \mathrm{C}$ for $1 \mathrm{~min}$, and then a final temperature of $72^{\circ} \mathrm{C}$ for $10 \mathrm{~min}$. Signals were normalized against $\beta$-actin. Primers for $\beta$-actin were: sense $5^{\prime}$-GAC TAC CTC ATG AAG ATC CT-3', antisense 5'-GCG GAT GTC CAC GTC ACA CT-3'.

Human primer sequence were: VIPR-1 sense 5'-CTT CTG GTC GCC ACA GCT ATC CTG-3', antisense 5'-ACT GCT GTC ACT CTT CCT GAT ATC-3'; VIPR-2 sense 5'-CGT CAC GGT GCC CTG CCC AAA AGT-3', antisense 5'-GCC CCT CAC AGC AGC CAG AAG A-3' (Park et al., 1996). Glyceraldehyde-3-phosphate dehydrogenase (GAPDH) was used as an internal control. Primers for GAPDH were: sense 5'-GGT GAA GTT CGG AGT CAA CGG A-3', antisense 5'-GAG GGA TCT CGC TCC TGG AAG A-3' (Sanfilippo et al., 2000). The PCR protocol was: denaturation at $94^{\circ} \mathrm{C}$ for $3 \mathrm{~min}$, followed by 40 cycles at $94^{\circ} \mathrm{C}$ for 1 min, $60^{\circ} \mathrm{C}$ for $2 \mathrm{~min}$, and $72^{\circ} \mathrm{C}$ for $3 \mathrm{~min}$.

PCR products were visualized by electrophoresis on $1.5 \%$ agarose gels and stained with ethidium bromide. Partial PCR products were directly sequenced using an ABI 3100 sequencer (Applied Biosystems; Foster City, CA, USA).

\section{Statistical analysis}

Data are reported as the means \pm standard deviation (SD). Statistical comparisons were conducted by one-way analysis of variance. $\mathrm{P}<0.05$ was considered to be statistically significant. All statistical analyses were carried out using the SPSS 17.0 (SPSS Inc.; Chicago, IL, USA).

\section{RESULTS}

\section{Purity of CD34+ cells}

The average number of CD34 $4^{+}$cells for each cord blood sample was $5 \times 10^{4}-5 \times 10^{5}$. The proportion of viable cells was determined by trypan blue staining and was greater than $96 \%$ in all samples. The purity of $\mathrm{CD} 34^{+}$cells detected by fluorescence-activated cell sorting (flow cytometry) was greater than $98 \%$ in all samples (Figure 1).

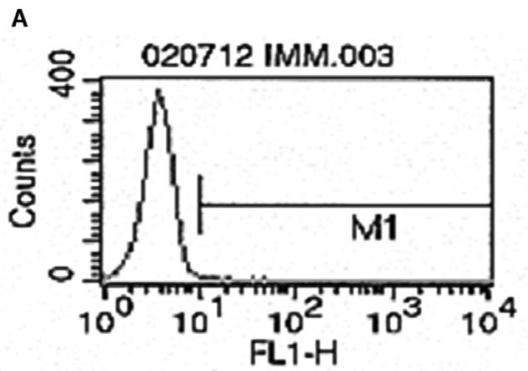

File: 020712 IMM.003

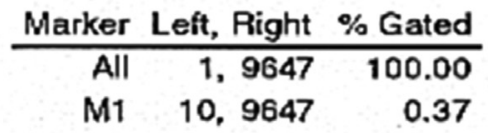

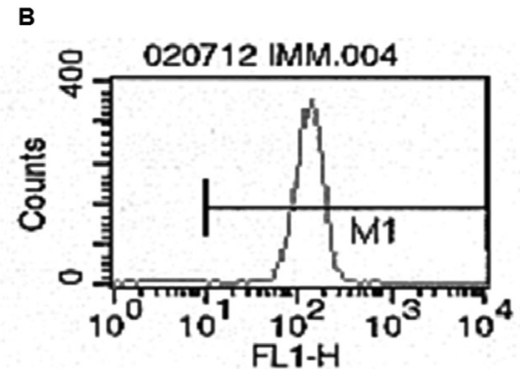

File: 020712 IMM.004

\begin{tabular}{rrr} 
Marker & Left, Right & $\%$ Gated \\
\hline All & 1. 9647 & 100.00 \\
M1 & 10,9647 & 98.79
\end{tabular}

Figure 1. Flow cytometry analysis of $\mathrm{CD} 34^{+}$cell purity. A. Negative control. B. Labeled human cord blood CD34 cells. M1: rate of $\mathrm{CD} 34^{+}$cells. 


\section{Effects of VIP on $\mathrm{CD}^{+}{ }^{+}$cells proliferation}

Purified CD34 ${ }^{+}$cells grew well in liquid culture and in clonogenic culture. After incubation with VIP, the CFUs of $\mathrm{CD} 34^{+}$cells were markedly decreased. Inhibiting factors were VIP concentration (ranged from $10^{-7}-10^{-12} \mathrm{M}$ ) and time (7-14 days) (Figure 2A). VIP at $10^{-8}$ $\mathrm{M}$ at day 10 showed the highest suppression. At this concentration, the proliferation rates of CD34 $4^{+}$cells were $11.78 \pm 4.39,16.71 \pm 2.98$, and $21.69 \pm 3.28$ at days 7,10 , and 14 , respectively. These values were significantly lower $(\mathrm{P}<0.05)$ than those of the control group (CD34 cells without VIP: $20.13 \pm 3.32,25.64 \pm 3.81$, and $28.33 \pm 2.61$, at days 7, 10, and 14, respectively) (Figure 2B).
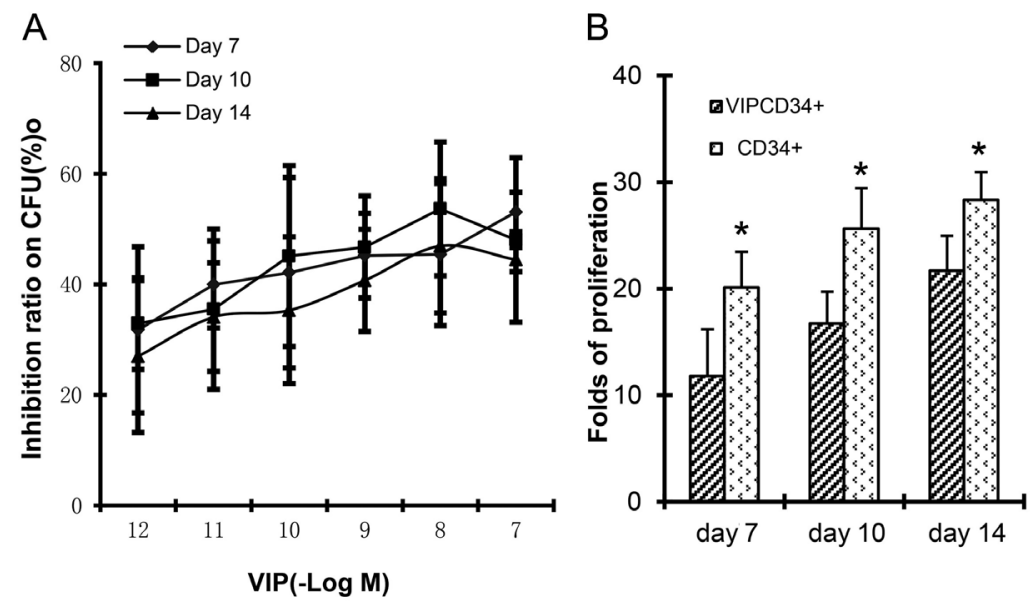

Figure 2. Effects of vasoactive intestinal polypeptide (VIP) on the proliferation of human $\mathrm{CD}_{3} 4^{+}$cells. A. Inhibitive effects of VIP on CFUs of CD34+ cells. CD34 $4^{+}$cells were cultured for CFUs in methylcellulose medium with different concentrations of VIP. Presented as the means \pm SD from 6 separate experiments in triplicate. B. Effects of VIP on the proliferation of CD $34^{+}$cells. CD $34^{+}$cells were cultured in a liquid system with/without VIP. Data are reported as the means $\pm \mathrm{SD}$ from 6 separate experiments in duplicates. ${ }^{*} \mathrm{P}<0.05 v s \mathrm{CD} 34^{+}$cells incubated with VIP.

\section{Effects of VIP on TNF- $\alpha$ and TGF- $\beta_{1}$ levels in CD34 ${ }^{+}$cells}

Levels of intracellular TNF- $\alpha$ and TGF- $\beta_{1}$ in CD34 cells treated with VIP were increased by 50.70 and $43.46 \%$, respectively, compared with control cells $(\mathrm{P}<0.05)$. Similarly, the levels of TNF- $\alpha$ and TGF- $\beta_{1}$ in the supernatant were increased by 31.70 and $42.64 \%$, respectively, compared with controls $(\mathrm{P}<0.05)$ (Table 1).

Table 1. TNF- $\alpha$ and TGF- $\beta_{1}$ levels in CD34 ${ }^{+}$cells stimulated by VIP $(\mathrm{pg} / \mathrm{mL})$.
\begin{tabular}{lllll}
\hline Group & \multicolumn{2}{c}{ TNF- $\alpha(\mathrm{N}=3)$} & \multicolumn{2}{c}{ TGF- $\beta_{1}(\mathrm{~N}=3)$} \\
\cline { 2 - 4 } & Intracellular & Extracellular & Intracellular & Extracellular \\
\hline Control & $247.59 \pm 6.80$ & $646.52 \pm 4.78$ & $168.41 \pm 8.65$ & $200.13 \pm 3.24$ \\
VIP & $373.11 \pm 7.40^{*}$ & $851.48 \pm 5.01^{*}$ & $241.60 \pm 7.67 *$ & $285.47 \pm 5.33^{*}$ \\
\hline VIP = vasoactive intestinal polypeptide. Control: unstimulated cells. *P $<0.05$ vs control.
\end{tabular}




\section{Variation of hepatic VIP concentrations and VIPR binding capacity during rat development}

VIP concentrations (ng/g tissue) in liver tissues from 4 phases of rat development were $13.49 \pm 2.20$ in fetuses, $14.40 \pm 3.94$ in neonates, $26.90 \pm 2.28$ in prematures, and 19.12 \pm 4.53 in adults. Hepatic VIP concentrations in the fetal and neonatal phase were significantly lower than those in the premature or adult phase $(\mathrm{P}<0.05)$. Among all 4 phases, hepatic VIP levels were the highest during the premature phase. The livers of adult rats contained less VIP than did the livers of premature rats, but still showed a significant increase in VIP levels compared with the livers of fetal and neonatal rats $(\mathrm{P}<0.05)$ (Figure $3 \mathrm{~A})$.
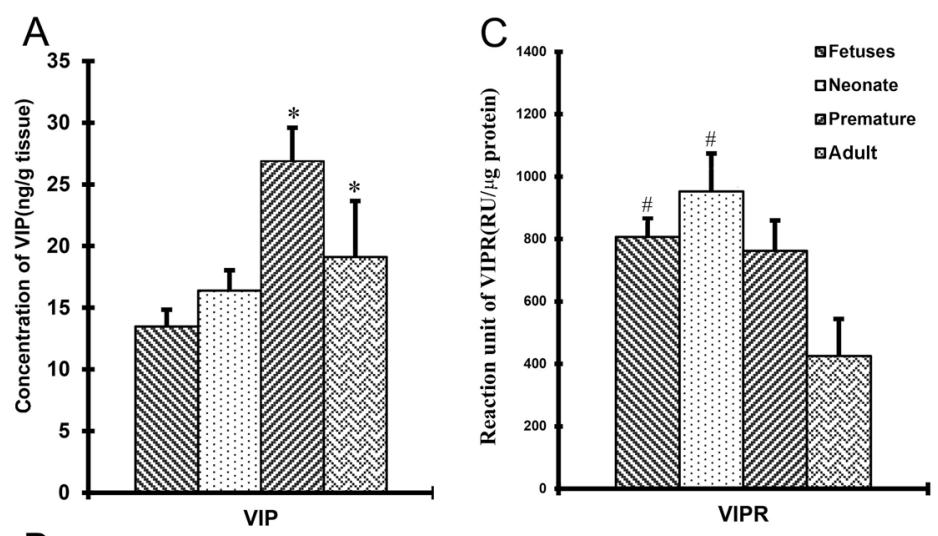

B

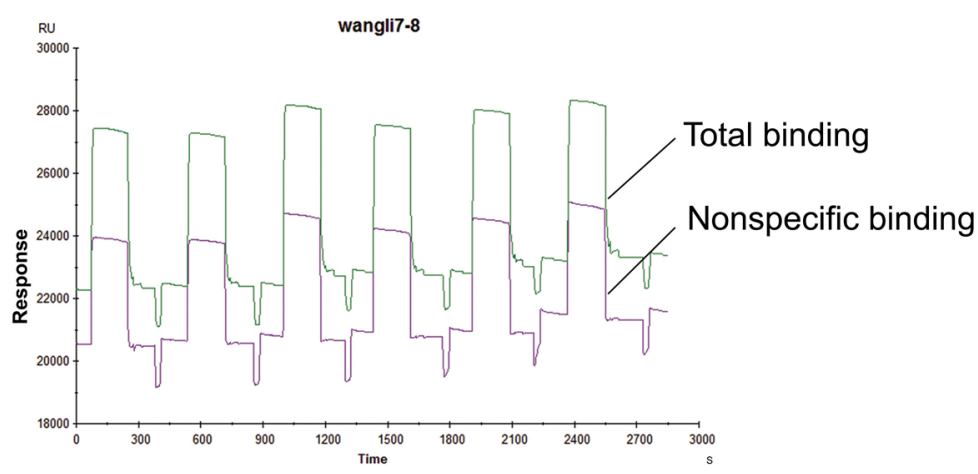

Figure 3. Variations in hepatic vasoactive intestinal polypeptide (VIP) levels and vasoactive intestinal polypeptide receptor (VIPR) binding during rat development. A. Extracts of rat liver tissue homogenates during the 4 development stages were collected to determine VIP levels using a radioimmunology assay. ${ }^{*} \mathrm{P}<0.05$ vs other phases. B. VIPR binding value with VIP was measured with a biosensor assay. Total protein containing VIPR was extracted from the liver tissue. $\mathrm{RU}=$ resonance units counted from surface plasmon resonance in the biomolecular interaction analysis system. Data show the average of 3 separate experiments in which duplicate determinations were made. ${ }^{\mathrm{P}}$ $<0.05 v s$ other phases. C. Raw binding curves of VIP-VIPR binding from rat liver tissue generated by the BIAcore software. Pure VIP was immobilized on BIAcore sensor chips CM-5 after activation. Total proteins containing VIPR extracted from the liver tissue were injected onto an immobilized VIP protein chip. The raw data from individual binding experiments were determined using the BIA evaluation software. Each experiment generated a non-specific binding value and a total binding value before and after the protein was injected. Specific binding = total binding nonspecific binding. The data were normalized to RU/ $\mu \mathrm{g}$ protein. 
Ligand-receptor binding curves plotted using the BIAcore biosensor system displayed specific binding for VIP in all rat hepatic tissues (Figure 3B). The binding capacities (RU/ $\mu \mathrm{g}$ protein) of VIPR in the different phases of development were $806.67 \pm 58.47$ in fetuses, 952.5 \pm 121.48 in neonates, $762.5 \pm 97.15$ in prematures, and $425 \pm 119.38$ in adults. The binding capacities of hepatic VIPR in the developmental phases before maturation were significantly higher than those in the adult phase $(\mathrm{P}<0.05)$. Neonatal rat livers expressed the highest levels of VIPR during development (Figure 3C).

\section{Determination of VIPR subtype in rat liver and human $\mathrm{CD34}^{+}$cells}

RT-PCR analysis revealed 2 products of 612 base pairs (bp) and $313 \mathrm{bp}$ (Figure 4A). The former was sequenced and was shown to be VIPR-1, while the latter was $\beta$-actin. No product was detected using primers specific for VIPR-2. The $\beta$-actin transcript was used as a control. These results showed that liver tissue samples from all phases of rat development only expressed VIPR-1 mRNA.

A

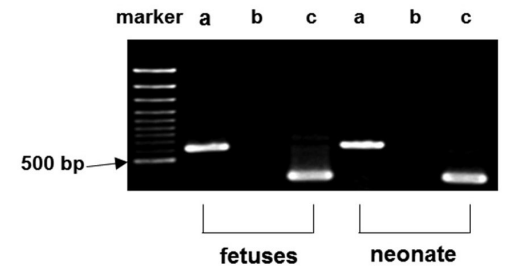

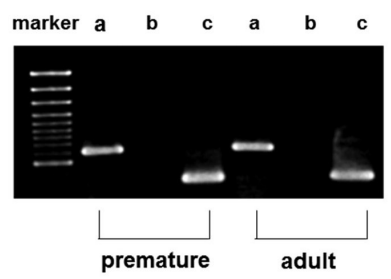

B

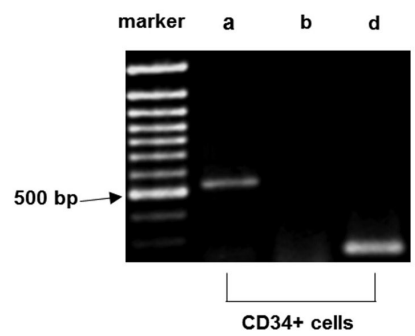

Figure 4. Semi-quantitative RT-PCR for VIP receptors in liver tissue and CD $34^{+}$cells. A. RT-PCR for VIPR-1 and VIPR-2 were performed in RNA extracted from the rat liver tissue of 4 different developmental stages. Lane $a=$ product cDNA at $612 \mathrm{bp}$. Lane $b=\mathrm{VIPR}-2$ PCR product. Lane $c=$ product cDNA of $\beta$-actin at $313 \mathrm{bp}$. B. RT-PCR with purified human cord blood-derived CD $34^{+}$cells for VIPR-1 and VIPR-2. Lane $a=$ VIPR-1 PCR product at $534 \mathrm{bp}$. Lane $b=$ VIPR-2 PCR product. Lane $d=$ GAPDH PCR product at $240 \mathrm{bp}$. Three separate experiments were performed in duplicate.

In human CD34+ cells, 2 products of 534 and 240 bp were detected (Figure 4B). The former was sequenced and found to be VIPR-1. No product was detected for VIPR-2. GAPDH was used as a control. These results show that human cord blood-derived CD34+ cells expressed VIPR-1 mRNA.

\section{DISCUSSION}

Hematopoietic stem cells and progenitors (HSCs/HPs) give rise to all blood and immune cells, and both play an important role in the human body. They are involved in the development, maintenance, and regeneration of blood cells (Rossi et al., 2008). HSCs/HPs have no specific morphological features, and cell surface antigens are the only way to distinguish HSCs/HPs from other cell types (Seita and Weissman, 2010). The CD34 antigen is a major surface marker of HSCs/HPs. Self-renewing HSCs express CD34 for life, whereas selfrenewing HPs express CD34 for only 6-8 weeks (Shizuru et al., 2005; Nielsen and McNagny, 
2009). CD $34^{+}$and CD38- cells are considered the best markers of HSCs because these cells have the ability to reconstitute blood constituents (Ojeda-Uribe et al., 2004; Pierre-Louis et al., 2009; Kuranda et al., 2011). However, most CD $34^{+}$cells co-express the CD38 antigen. The bone marrow contains only $5-10 \%$ of $\mathrm{CD}^{2} 4^{+}$cells (Hanazono et al., 2002), and these cells are rarely CD38- (Yahata et al., 2008), limiting their use in research and in the clinical setting. It is well-known that $\mathrm{CD} 34^{+}$cells, including HSCs/HPs, can reconstitute blood in rats and humans. These cells are abundantly present in umbilical cord blood and are located in the fetal liver and spleen before migrating to the bone marrow (Ghanem et al., 2012). These cells have been widely used in clinical hematopoietic cell transplantation (HCT). Hence, in this study, we chose human cord blood-derived $\mathrm{CD} 34^{+}$cells as our cell model and purified $\mathrm{CD} 34^{+}$cells using CD $34^{+}$magnetic beads.

The first major finding of the present study was that VIP exerts inhibitory effects on the proliferation and colony formation of cord blood-derived HSCs/HPs, with VIP acting directly on the $\mathrm{CD} 34^{+}$progenitors; this effect reached a maximum at $10^{-8} \mathrm{M}$ VIP. This result is in accordance with those described in a previous report (Rameshwar et al., 2002) showing that VIP inhibited the proliferation of bone marrow progenitors. Although cytokines are known to be very important molecules affecting the proliferation of HSCs/HPs and are considered to be regulators of HSCs/HPs, few cytokines have been reported to inhibit hematopoiesis, such as TNF- $\alpha$, TGF- $\beta$, and PF4 (Lambert et al., 2009; Sharma et al., 2011; Wang et al., 2012). In this study, we not only confirmed the inhibitory effect of VIP on the amplification of CD $34^{+}$cells purified from human cord blood samples, but also revealed that VIP upregulated the intrinsic levels of TNF- $\alpha$ and TGF- $\beta_{1}$ in CD $34^{+}$cells. Therefore, VIP can be considered to be a negative humoral regulator of HSC/HP proliferation. Because of the negative effects of VIP on HSC/ HP proliferation, it is important to measure hepatic VIP levels during different developmental phases.

The second major finding of this study was that we described the changes in hepatic VIP levels from the embryo to adult stages. VIP concentrations in the liver were relatively low in fetuses but high in neonates, showing a rapid increase during development. After birth, hepatic VIP levels peaked during the premature stage. In addition, the affinity of VIPR for VIP in the liver increased from relatively low in fetuses to a high level in neonates, reaching a maximum at birth and then gradually decreasing thereafter. This may result in low VIP levels in the fetal liver, but gradually higher levels after birth. Taken together, the relatively low VIP levels in the fetal liver may be beneficial for liver hematopoiesis. As hepatic VIP levels increased rapidly after birth, these changes in VIP levels may be partly responsible for the suppression of $\mathrm{HSC} / \mathrm{HP}$ proliferation in the liver after birth. The hepatic microenvironment, which was rich in VIP from the neonate to the premature phase, would not be suitable for HSC/HP proliferation. Although increased VIP levels observed in neonates were not maintained in adults, the levels were greater than in fetuses, and may contribute to the inhibition of hepatic hematopoiesis during adult life.

The VIPR family includes 2 subtypes: VIPR-1 and VIPR-2 (Gozes and Furman, 2004). Both are $G$ protein-coupled receptors that can activate adenylate cyclase. In this study, VIPR-1 was detected in both the fetal liver and in HSCs/HPs, strongly suggesting that VIP exerts its functions via VIP-VIPR binding. The present study showed that VIPR-1 was detected in the rat liver throughout every stage of development. VIP receptors are widely distributed in many different rat tissues (Harmar et al., 2004; Erdling et al., 2013). Quantification of VIPR activation is difficult because of the low sensitivity and specificity of techniques established. 
Therefore, various studies have instead detected VIPR mRNA. To obtain more accurate data on liver VIPR levels during rat development, a biomolecular interaction analysis system using the surface plasmon resonance technique (de Mol, 2012) was used in this study to detect active VIPR binding to VIP. It has been reported that VIPR mRNA was detected as early as rat embryonic day 11 in the neuronal epithelium, foregut, heart, and blood vessels. From embryonic days 14-18, VIPR mRNA was detected in tissues derived from all 3 germ layers (Pei, 1997). These data suggest that binding of VIP to VIPR may play an important role not only in rat embryonic development, but also in the process of vascular development (Erdling et al., 2013). Low VIPR levels in fetal livers observed in the present study may facilitate the development of liver vessels, which is also necessary for the hematopoietic microenvironment and therefore may indicate hepatic development.

In summary, this study demonstrated that VIP suppressed the proliferation of human cord blood-derived CD $34^{+}$cells in part by increasing the production of TNF- $\alpha$ and TGF- $\beta$. Low VIP levels in the fetal liver and gradually higher levels after birth may be responsible for the suppression of HSC/HP proliferation in the liver. VIP was identified as an inhibitor of hepatic hematopoiesis.

\section{Conflicts of interest}

The authors declare no conflict of interest.

\section{ACKNOWLEDGMENTS}

Research partially supported by the National Natural Science Foundation of China (\#30971277; \#30972789; \#81250034).

\section{REFERENCES}

de Mol NJ (2012). Surface plasmon resonance for proteomics. Methods Mol. Biol. 800: 33-53.

Erdling A, Sheykhzade M, Maddahi A, Bari F, et al. (2013). VIP/PACAP receptors in cerebral arteries of rat: characterization, localization and relation to intracellular calcium. Neuropeptides 47: 85-92.

Fiegel HC, Kluth J, Lioznov MV, Holzhuter S, et al. (2003). Hepatic lineages isolated from developing rat liver show different ways of maturation. Biochem. Biophys. Res. Commun. 305: 46-53.

Ghanem LY, Nosseir MM, Lotfi AA, Mohamed AS, et al. (2012). Hematopoietic stem cell mobilization into the peripheral circulation in patients with chronic liver diseases. J. Dig. Dis. 13: 571-578.

Gozes I and Furman S (2004). Clinical endocrinology and metabolism. Potential clinical applications of vasoactive intestinal peptide: a selected update. Best Pract. Res. Clin. Endocrinol. Metab. 18: 623-640.

Hanazono Y, Terao K, Shibata H, Nagashima T, et al. (2002). Introduction of the green fluorescent protein gene into hematopoietic stem cells results in prolonged discrepancy of in vivo transduction levels between bone marrow progenitors and peripheral blood cells in nonhuman primates. J. Gene Med. 4: 470-477.

Harmar AJ, Sheward WJ, Morrison CF, Waser B, et al. (2004). Distribution of the VPAC2 receptor in peripheral tissues of the mouse. Endocrinology 145: 1203-1210.

Khurana S, Jaiswal AK and Mukhopadhyay A (2010). Hepatocyte nuclear factor-4 $\alpha$ induces transdifferentiation of hematopoietic cells into hepatocytes. J. Biol. Chem. 285: 4725-4731.

Kim DH, Park IH, Cho JS, Lee YM, et al. (2011). Alterations of vasoactive intestinal polypeptide receptors in allergic rhinitis. Am. J. Rhinol. Allergy 25: e44-e47.

Kuranda K, Vargaftig J, de la Rochere P, Dosquet C, et al. (2011). Age-related changes in human hematopoietic stem/ progenitor cells. Aging Cell 10: 542-546.

Lambert MP, Wang Y, Bdeir KH, Nguyen Y, et al. (2009). Platelet factor 4 regulates megakaryopoiesis through lowdensity lipoprotein receptor-related protein 1 (LRP1) on megakaryocytes. Blood 114: 2290-2298. 
Leister I, Sydow J, Stojanovic T, Füzesi L, et al. (2005). Impact of vasoactive intestinal polypeptide and gastrin-releasing peptide on small bowel microcirculation and mucosal injury after hepatic ischemia/reperfusion in rats. Int. J. Colorectal Dis. 20: 42-48.

Misbin RI, Wolfe MM, Morris P, Buynitzky SJ, et al. (1982). Uptake of vasoactive intestinal peptide by rat liver. Am. J. Physiol. 243: G103-G111.

Nielsen JS and McNagny KM (2009). CD34 is a key regulator of hematopoietic stem cell trafficking to bone marrow and mast cell progenitor trafficking in the periphery. Microcirculation 16: 487-496.

Ohnami S, Matsumoto N, Nakano M, Aoki K, et al. (1999). Identification of genes showing differential expression in antisense K-ras-transduced pancreatic cancer cells with suppressed tumorigenicity. Cancer Res. 59: 5565-5571.

Ojeda-Uribe M, Sovalat H, Bourderont D, Brunot A, et al. (2004). Peripheral blood and BM CD34+ CD38- cells show better resistance to cryopreservation than $\mathrm{CD} 34^{+} \mathrm{CD} 38^{+}$cells in autologous stem cell transplantation. Cytotherapy 6: 571-583.

Park SK, Olson TA, Ercal N, Summers M, et al. (1996). Characterization of vasoactive intestinal peptide receptors on human megakaryocytes and platelets. Blood 87: 4629-4635.

Pei L (1997). Genomic structure and embryonic expression of the rat type 1 vasoactive intestinal polypeptide receptor gene. Regul. Pept. 71: 153-161.

Pierre-Louis O, Clay D, Brunet dlG, Blazsek I, et al. (2009). Dual SP/ALDH functionalities refine the human hematopoietic Lin-CD34 ${ }^{+}$CD38- stem/progenitor cell compartment. Stem Cells 27: 2552-2562.

Rameshwar P, Gascon P, Oh HS, Denny TN, et al. (2002). Vasoactive intestinal peptide (VIP) inhibits the proliferation of bone marrow progenitors through the VPAC1 receptor. Exp. Hematol. 30: 1001-1009.

Rossi DJ, Jamieson CH and Weissman IL (2008). Stems cells and the pathways to aging and cancer. Cell 132: 681-696.

Sanfilippo L, Li CK, Seth R, Balwin TJ, et al. (2000). Bacteroides fragilis enterotoxin induces the expression of IL-8 and transforming growth factor- $\beta$ (TGF- $\beta$ ) by human colonic epithelial cells. Clin. Exp. Immunol. 119: 456-463.

Sato EF, Nakagawa E, Hiramoto K, Yamamasu S, et al. (2004). Oxidative stress promotes the regression of fetal liver hemopoiesis. Biochemistry 69: 18-22, 1.

Schmelzer E, Deiwick A, Bruns H, Fiegel HC, et al. (2008). Thrombopoietin is a growth factor for rat hepatic progenitors. Eur. J. Gastroenterol. Hepatol. 20: 209-216.

Seita J and Weissman IL (2010). Hematopoietic stem cell: self-renewal versus differentiation. Wiley Interdiscip. Rev. Syst. Biol. Med. 2: 640-653.

Sharma B, Altman JK, Goussetis DJ, Verma AK, et al. (2011). Protein kinase R as mediator of the effects of interferon (IFN) gamma and tumor necrosis factor (TNF) $\alpha$ on normal and dysplastic hematopoiesis. J. Biol. Chem. 286: 27506-27514.

Shizuru JA, Negrin RS and Weissman IL (2005). Hematopoietic stem and progenitor cells: clinical and preclinical regeneration of the hematolymphoid system. Annu. Rev. Med. 56: 509-538.

Si-Tayeb K, Lemaigre FP and Duncan SA (2010). Organogenesis and development of the liver. Dev. Cell 18: 175-189.

Smalley SG, Barrow PA and Foster N (2009). Immunomodulation of innate immune responses by vasoactive intestinal peptide (VIP): its therapeutic potential in inflammatory disease. Clin. Exp. Immunol. 157: 225-234.

Sreepriya M and Bali G (2006). Effects of administration of Embelin and Curcumin on lipid peroxidation, hepatic glutathione antioxidant defense and hematopoietic system during N-nitrosodiethylamine/Phenobarbital-induced hepatocarcinogenesis in Wistar rats. Mol. Cell Biochem. 284: 49-55.

Tober J, McGrath KE and Palis J (2008). Primitive erythropoiesis and megakaryopoiesis in the yolk sac are independent of c-myb. Blood 111: 2636-2639.

Turtzo LC, Marx R and Lane MD (2001). Cross-talk between sympathetic neurons and adipocytes in coculture. Proc. Natl. Acad. Sci. U. S. A. 98: 12385-12390.

Usdin TB, Bonner TI and Mezey E (1994). Two receptors for vasoactive intestinal polypeptide with similar specificity and complementary distributions. Endocrinology 135: 2662-2680.

Wang C, Tang X, Sun X, Miao Z, et al. (2012). TGF $\beta$ inhibition enhances the generation of hematopoietic progenitors from human ES cell-derived hemogenic endothelial cells using a stepwise strategy. Cell Res. 22: 194-207.

Yahata T, Muguruma Y, Yumino S, Sheng Y, et al. (2008). Quiescent human hematopoietic stem cells in the bone marrow niches organize the hierarchical structure of hematopoiesis. Stem Cells 26: 3228-3236. 